\title{
CORRIGENDUM
}

\section{High-dose therapy and autologous hematopoietic cell transplantation as front-line consolidation in chronic lymphocytic leukemia: a systematic review}

T Reljic, A Kumar, B Djulbegovic and MA Kharfan-Dabaja

Bone Marrow Transplantation (2015) 50, 1144; doi:10.1038/bmt.2015.126

Correction to: Bone Marrow Transplantation (2015) 50, 10691074; doi:10.1038/bmt.2015.69; published online 13 April 2015

Since the online publication of the above article, the authors have noted that reference 5 is incorrect. The correct reference is:

5. Döhner $H$, Stilgenbauer $S$, Benner A, Leupolt $E$, Kröber A, Bullinger $L$ et al. Genomic aberrations and survival in chronic lymphocytic leukemia. N Engl J Med 2000; 343: 1910-1916.

The authors would like to apologise for this error.

This error has now been rectified, and the corrected article appears in this issue. The html and online pdf versions have also been rectified, and now carry the corrected paper. 